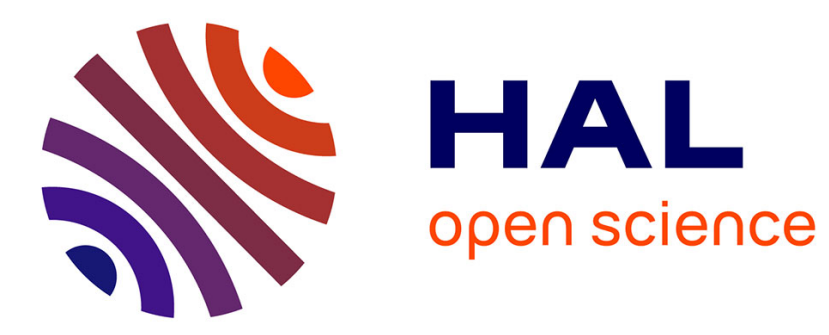

\title{
Translation and Trauma
}

Élise Pestre, Fethi Benslama

\section{To cite this version:}

Élise Pestre, Fethi Benslama. Translation and Trauma. Recherches en psychanalyse, 2011, Perspectives contemporaines / Current Perspectives, 1 (11), pp.18 - 28 10.3917/rep.011.0213 . hal-01502504

\section{HAL Id: hal-01502504 https://hal.science/hal-01502504}

Submitted on 5 Apr 2017

HAL is a multi-disciplinary open access archive for the deposit and dissemination of scientific research documents, whether they are published or not. The documents may come from teaching and research institutions in France or abroad, or from public or private research centers.
L'archive ouverte pluridisciplinaire HAL, est destinée au dépôt et à la diffusion de documents scientifiques de niveau recherche, publiés ou non, émanant des établissements d'enseignement et de recherche français ou étrangers, des laboratoires publics ou privés. 


\title{
TRANSLATION AND TRAUMA
}

\author{
Élise Pestre, Fethi Ben Slama
}

\section{Association Recherches en psychanalyse | «Recherches en psychanalyse »}

2011/1 $n^{\circ} 11 \mid$ pages 18a à 28a

ISSN 1767-5448

Article disponible en ligne à l'adresse :

http://www.cairn.info/revue-recherches-en-psychanalyse-2011-1-page-18a.htm

\section{Pour citer cet article :}

Élise Pestre, Fethi Ben Slama, «Translation and Trauma », Recherches en psychanalyse 2011/1 ( $\left.\mathrm{n}^{\circ} 11\right)$, p. 18a-28a.

DOI 10.3917/rep.011.0213

Distribution électronique Cairn.info pour Association Recherches en psychanalyse.

(C) Association Recherches en psychanalyse. Tous droits réservés pour tous pays.

La reproduction ou représentation de cet article, notamment par photocopie, n'est autorisée que dans les limites des conditions générales d'utilisation du site ou, le cas échéant, des conditions générales de la licence souscrite par votre établissement. Toute autre reproduction ou représentation, en tout ou partie, sous quelque forme et de quelque manière que ce soit, est interdite sauf accord préalable et écrit de l'éditeur, en dehors des cas prévus par la législation en vigueur en France. Il est précisé que son stockage dans une base de données est également interdit. 


\title{
Recherches en Psychanalyse - Research in Psychoanalysis
}

$11 \mid 2011$ - Current Perspectives

Perspectives contemporaines

\section{Translation and Trauma}

\author{
Traduction et traumatisme
}

\section{Élise Pestre \\ Fethi Benslama}

\begin{abstract}
:
Political and social violence can have destructive effects not only on individual subjects but also on their descendants. How can one construct oneself in the presence of a silent traumatic heritage? Can such trauma be symbolized and translated, and if so, how can this be accomplished? The study of the life path of Janine Altounian, the author of several works on the effect of violence transmitted across the generations, and herself a descendant of parents who escaped the Armenian genocide, shows us a subjective attempt to translate one such traumatic heritage. More generally, clinical work with refugees allows us to think about the use of translation in the cases of individuals whose subjective foundations have been severely damaged by the trials of the real.
\end{abstract}

\section{Résumé :}

Les violences politiques et sociales ont le pouvoir d'engendrer des effets destructeurs sur le sujet mais, au-delà, sur sa descendance. Comment peut-on se construire lorsqu'on hérite de silences traumatiques ? Existe-t-il des possibilités de symbolisation et de traductions de ces traumatismes ? Et si oui, de quelle manière peuvent-elles s'instaurer ? L'étude de la trajectoire de Janine Altounian, auteur de plusieurs ouvrages sur les effets de ces violences transmises entre générations et elle-même descendante de parents rescapés du génocide arménien, rend compte des tentatives subjectives de traduction d'un héritage traumatique. Plus généralement, la clinique des réfugiés permettra d'envisager le déploiement de la traduction, à l'œuvre chez ceux dont les assises subjectives ont été profondément mises à mal par l'épreuve du réel.

Keywords: trauma, translation, clinical work with refugees, reterritorialization, language

Mots-clefs : traumatisme, traduction, clinique des réfugiés, reterritorialisation, langue

\author{
Plan: \\ Trauma and Heritage \\ The Possibilities of Translation \\ The Displacements in Language \\ The Symbologenic Power of Writing \\ Publishing the Text \\ The Hospitality of Language \\ From One Shore to the Other
}


In the limits to which it is possible, or at least appears possible, translation practices the difference between signified and signifier. But if this difference is never pure, no more is translation and for the notion of translation we would have to substitute a notion of transformation: a regulated transformation of one language by another, of one text by another. We will never have, and in fact never have had, to do with some 'transport' of pure signifieds

from one language to another, or within one and the same language, that the signifying instrument -or 'vehicle' - would leave virgin and untouched. Jacques Derrida, Semiology and Grammatology ${ }^{I}$

The barbarism unleashed during the $20^{\text {th }}$ century has, retrospectively, been the subject of a number of clinical and theoretical studies focusing on populations that have survived these collective tragedies. ${ }^{2}$ When a subject has experienced certain extreme situations and narrowly escaped death, the events disrupting his life may lead to the formation of trauma. Though they are anchored in the present, such events possess a traumatic potential, one that is able to profoundly disorganize the narcissistic foundations of the subject's psyche, striking at the heart of his identity. Indeed, human cruelty has the power to attack the subjective and social constructions that are at the very basis of our being in the world.

The subjective effects of such attempts at dehumanization, inflicted on humans by other humans, raise the question of an epistemological breakpoint in the history of trauma. For the first time in history, the possibility emerges of an exogenous historical event so violent and totalitarian that it remains completely outside the possibilities of subjective integration. In this new dimension, the impact of "extreme trauma," including political, social and psychic elements, comes to question certain psychoanalytic theories, which avoid the dimension of external incidents in favor of the internal and fantasmatic event.

Consequently, it has been observed that the populations that have survived mass murders of this kind are forced to repeat, beyond their own generation and through their descendants, a collective past that had escaped them. In certain cases, these descendants become the only continent capable of receiving the unresolved wrongs of the ancestral survivors. The power of the collective violence experienced has often had the effect of silencing the ancestors that escaped unharmed, yet are not free of the cruel past. In the context of survival, the unsaid often accumulates and is transmitted "en bloc" to the heirs. It then forms a dense and opaque mass, composed of enigmatic contents and buried memory traces, which nonetheless remain alive in the heir's psyche. These silenced events have disastrous consequences and remain psychically active throughout the person's entire life.

When trauma of this type has been transmitted and inherited with no transformation, the infantile psyche is constructed as captive to another's memory, one that is perceived by the subject as both strange and familiar and generally troublesome. In this situation, how is the heir of these traumatic silences able to construct himself and evolve? Can such traumas be symbolized and translated? And if the answer is yes, how can this be done?

In order to study the avatars of traumatic intergenerational transmission, we will begin by looking at what the translator and essayist Janine Altounian has called "survivance." ${ }^{3}$ We are going to explore the singular life path of the author, and in the light of her most recent book, a collective work entitled Mémoires du génocide arménien, héritage traumatique et travail analytique [Memories of the Armenian Genocide, Traumatic Heritage and Analytic Work], ${ }^{4}$ we will consider the ways in which she carries out a real work of translating these traumas through writing and working with language. The architecture of Altounian's book in fact allows us to see how a subject may try to appropriate and transform - unsuccessfully the elements transmitted to her by her ancestors, in order to free herself of survival.

More generally, we are going to look at the approach to working clinically with refugee populations. This will enable us to think about engaging in a praxis directed at metaphorizing 
and translating trauma, in a situation where we are confronted with what appears to be simply untranslatable. ${ }^{5}$ In a register that lies just shy of the symbolic laws of language, what can the analyst or clinical psychologist "do" with the traumatic material brought to him by the patient? Should and can he facilitate the translation of certain traumatic scenes, in order to give meaning to memory gaps that have been transmitted to these patients and to which they remain bound? We are going to suggest several possible clinical directions in order to approach the reality of working with a refugee population and its descendants.

\section{Trauma and Heritage}

Of Armenian origin, Janine Altounian comes from a family that survived the 1915 Armenian genocide committed by the Turks. In the 1920s, her stateless family settles in exile in Lyon. Her father Vahram Altounian, a survivor, is still a young man.

A "good student," Janine Altounian enrolls at university to study literature. During her college years, she "accidently" (as she likes to say) stumbles across a school notebook, which her father kept at the age of nineteen, at the time of his arrival in France and after he had survived the Catastrophe. ${ }^{6}$ Its title: "All that I have suffered between 1915 and 1919." Upon the discovery of the manuscript Janine Altounian embarks on a period of intense elaboration. She begins to write, relentlessly, about her own experience as the daughter of a survivor. In parallel to her psychoanalysis, the "found" manuscript is repeatedly "reworked" through her work of writing and publishing. Her writing continues to clarify and give meaning to experiences which previously remained unnamable, like constantly remodeled clay.

Although she is primarily an essayist and a translator (from German to French), Janine Altounian's thinking and writing are infused with psychoanalysis. ${ }^{7}$ The author has developed an entire conceptual system related to the transmission, from survivor parents to their descendants, of what she calls the nonsymbolized and traumatic "remains" [restes]. She thinks of these deposits as having opted to lodge themselves in the psyche of the heir. The psychical and territorial suspension often largely immobilizes the subject's own capacity of evolution, sometimes with a truly "demonic" effect on the subject's life. ${ }^{8}$

\section{The Possibilities of Translation}

"Survivance" is transmitted through intersubjective ties and plays a central role in the heir's psyche. If no agency of separation intervenes, the unconscious injunction addressed by the survivor parents to their children - to remain the "mouthpiece" of their hi/story - will repeat across generations, since what has remained in abeyance in one person is inevitably repeated in the other. A true work of translation (from the Latin traducere), ${ }^{9}$ in the sense of moving from one place to another, must therefore take place if the subject, a child of the suffering exiled parents, wants to grow without falling prey to another's captivating and often destructive memory. However, the movement of the traumatic object from one point to another cannot alone remove the weight of the trauma, unless it transits an intermediary and symbologenic space. ${ }^{10}$ The subjective restitution of the modified object can therefore only take place once the displacement has produced a symbol.

In the case of Janine Altounian, this symbolic agency is embodied in writing, and it works to concretize a "latent" reading, initially nontranslated (in her case the father's manuscript written in his native language), to produce new and constantly evolving objects - new texts, thus promoting "a renewal of something living [in which] the original is undergoes a change," as Walter Benjamin says in his reflection on The Task of the Translator. ${ }^{11}$

Traumatic psychical context shows us to what extent the stakes of translation do not lie in a simple literary transcription of one language into another or in simple communication. A 
function of transference is established, so that something of a subject emerges through the operation of translation. This displacement, this transfer of an element, must take place so that the traumatic distortions can be traversed and take on a meaning for the subject - or for his heirs. In addition, the word "translation" shares its root with "transmission," "transference" or "to traverse," all of which contain the idea of displacing and transcending what the initial word designates. ${ }^{12}$

The symbolic agency which produces meaning can be represented by the subject's entrance into a language other than his own, but also by an act of writing or by an encounter with an analyst - simply put, by a third agency, an Other who triangulates what has remained undifferentiated, in this way helping the resumption of the process of symbolization. In the case of Janine Altounian, this third function was represented, as she herself describes it, by the French republican school system of the past, by the secular education introduced by Jules Ferry. $^{13}$

\section{The Displacements in Language}

Given today's globalized and inhospitable policies aimed at foreigners in general and asylum-seekers especially, the refugee is often excluded and politically marginalized. Deterritorialized, he "seeks a territory" 14 and must submit himself to a new legal authority, while the experience of deterritorialization has "destroyed all that a previous territorialization might have achieved." ${ }^{15}$ Condemned to survive in a state of permanent territorial and psychical "non-place" [non-lieu], the surviving refugee or his descendant is thus forced into legal but also subjective reterritorialization. With great accuracy, these neologisms coined by $\mathrm{G}$. Deleuze and F. Guattari ${ }^{16}$ express the necessary operation of translation, which implies a territorial displacement of traumatic affects, their expatriation from one place to another.

From this perspective, Altounian's hypothesis that it is ultimately impossible for the heirs of trauma to survive otherwise than by "adopting" another language ${ }^{17}$, appears useful in thinking about clinical work with refugees. Bit by bit, linguistic displacements re-cypher the trauma and, without any need to "wait for" the following generation, encourage the exiled person's own capacity of historicization. The subject emerging from a limbo must in fact "reterritorialize himself" in langage - and in langue - in order to "make" something of his traumatic past. Otherwise he will not be able to accede to symbol creation, which alone will allow him to exist otherwise than solely in survival. And if his attempts to translate trauma are thwarted, he will be able to live neither here nor there.

\section{The Symbologenic Power of Writing}

As a collective work published under the names of Vahram and Janine Altounian, Mémoires du génocide arménien, héritage traumatique et travail analytique [Memories of the Armenian Genocide: Traumatic Heritage and Analytic Work] includes texts written by several contemporary authors, psychoanalysts and experts in questions of testimony. With a variety of geographic backgrounds and temporalities, they are all nonetheless concerned with the same object: the manuscript of Janine Altounian's father. This work of "several voices," ${ }^{18}$ almost clinical in nature, further develops the textual model wereferred to earlier, which was created by Altounian herself and based on her own history, as well as that of others - using testimonies of survivors and their descendants - and as a result of her back-andforth movement between the humanities and literature. As an author, Altounian is indeed able to continuously build bridges between these disciplines and the testimonies of survivors' experience, resulting in the production of a singular piece of theoretical work.

For their part, the authors of this collective work focus on the analysis of Vahram Altounian's manuscript. By creating links between their own text and Vahram's, they too participate in a 
singular "reterritorialization," in solidarity with its heiress. The plurality of their writing, their different territorialities and the different crossings they make between this testimony and other cultural objects - literature, the history of cinema etc. - help extend and elaborate the fabric of words and meaning that Altounian previously began to weave. It is as though, through their work of making links, they were continuing to extract the text from its lethal context bound to the mutilating transmissions of mass murder.

We notice that the processes of translating trauma are active even in the structure of the book. In between the text of Janine Altounian's father and her own, we find an article written by the translator of the father's manuscript. ${ }^{19}$ The symbolic value of the position of the translator's article - between the father and the daughter shows, within this framework, the inexhaustible and necessary translation of trauma, in this case Janine Altounian's own trauma, a "translation of the paternal manuscript which must constantly be renewed." ${ }^{20}$

In this perspective of exploring the body of the work we also notice that the titles are always double and long, as is that of the work as a whole, marking the heir's endless effort to translate, in order to name, in order to try and use words to delimit what precisely remains inaccessible to language [both as langage and langue].

Even though it seems that the authors included in the final work were not trying to identify the beyond-meaning [hors-sens] of the Real - in such case they would find it impossible to delimit it entirely - it seems that together they have nonetheless managed to create a piece of memory. Contrary to a language [langue] that would remain mute, smooth and silent, the book forges links with other books, it produces difference. Going from one text to another and sometimes from one language to another, the translation process at work aims to symbolically close up the fissure opened by the Real of the trauma that was transmitted.

Therefore, the multifaceted translation employed in this collective work took on various forms. The symbolic production began by translating the survivor's - the father's - text from one language to another, following his daughter's wishful impulse. It continued through her own work of writing, accompanied and nourished by that of others. We should also mention the theoretical elaboration of each of the participating authors, which too has facilitated the intelligibility of the traumatic experience. In the end, the process gives rise to the act of publication as the author-heiress' ultimate translation.

\section{Publishing the Text}

Although Janine Altounian experienced the publication of her father's manuscript as a "double transgression," as she herself puts it on the one hand, in relation to her traditional Eastern family, and on the other hand, in relation to her dead father - it is also represented as an act which imposes itself on her. Since 1975 Altounian has published five books on this subject, including at least two works in which she included the text of the manuscript. ${ }^{21}$ However, it was not until the last analyzed work that a true caesura was produced. Even more than writing, for Altounian it is the act of publication that seems to function as an enactment of the traumatic experience she inherited. This act makes her the creator of an object, which from now on belongs to her "in the flesh." This is because the author (from the Latin auctor) is indeed the one who stands "at the origin of something," a "creator." ${ }^{22} \mathrm{He}$ is also properly speaking "the one who increases" [accroît], who intensifies and potentiates an object. And if "translation issues from the original," ${ }^{23}$ we see here that a translation (not from one language into another but of one traumatic language into another which frees it of its burden) must become a work in itself, in order to survive and transcend the original. The path opened by the "constant renewal" inherent in translation is that of following one's own destiny, since its aim is, far from a simple replication, to accede to a "higher linguistic air." ${ }^{24}$ Still following the line of Benjamin's 
argument, we could say that thanks to this movement, "the mother tongue of the translator is transformed as well"25 - a hypothesis that hints at the transformative effects engendered by the translation of trauma into the heir's language.

By giving birth to her own text, the author takes a risk, burdens herself with and makes herself responsible ${ }^{26}$ for a text which has now been translated, thought through and published.

By authorizing herself as the other author of this book, Janine Altounian lets her father's voice be heard again. Publishing the text in both his mother's tongue (using Armenian alphabet) and his adopted language (French) she restores him to the rank of an author. The publication appears as a new foundational event, the basis of the reconstruction of a lost meaning. From the perspective of the transmission of testimony but also as a constantly renewed attempt at creating a link and presenting it to others, the different languages convey what seemed to have precisely remained just shy of language.

\section{The Hospitality of Language}

Like the translator, the clinical psychologist or the analyst working with refugees - or their heirs - can create a third space, so that the subject, unable to differentiate, attached to his traumatic pain, can accede to an agency which produces an other. The destruction of different topos - psychic, corporeal and spatial-temporal - induced by trauma, often "traps" the subject in a traumatic reality, where lack of differentiation is the rule. Reintroducing play, a medium, emerges as a therapeutic technique which allows the retracing of the "blurred" contours of various boundaries - between the body and the psyche, but also between the legal and the social fields. This also makes it possible to re(start) the processes of re-subjectivation. A transitional area in the Winnicottian sense - a space of potential, an intermediary and separating zone - can thus be created.

Although the intermediary may be embodied in the figure of the interpreter-translator who translates from one language to another, the function of translation in the space of transference cannot be reduced to this third presence. In addition to the figure of the messenger who organizes and participates in the creation of the intermediary space, the crucial role is played by the back-and-forth movement between the refugee's mother tongue and that of the host country. Offering the subject a site where he can circulate certain cultural themes, such as the myths that are part of his culture of origin or the way in which they intersect - or don't - with those of the host country, therefore represents one of the possible clinical modalities of facilitating psychical movement.

This is why the progressive inscription of refugee subjects in the language of the host country seems essential. If the translatorinterpreter initially acts as an instance of "transitionality," helping the subject enter the language of the host country in order to make do with these new signifiers may trigger operations of displacement which encourage "re-transitionnalization," thus permitting a rearranging of the trauma. The new linguistic codes reintroduce otherness where the subject had previously lost confidence in language. The subjective use and appropriation of a foreign language - which represents the potentially safe language of the living, or at least that of "the non-exterminable of the moment" ${ }^{27}$ - can then pave the way for the process of repression. However, we should question the "triangulating" potential of the language of a host country that precisely does not behave hospitably but instead rejects the subject. In such cases, can we expect the adopted language to emerge in the subject? And does this language preserve its symbolizing qualities or does it become inhospitable?

In order for the linguistic paths to become roads of re-subjectivation, the subject's language must not be bannished because nobody in a state of legal and political instability can hope to find proper anchorage.

The "borrowed" foreign language and its symbologenic function are also related to the 
question of the institutional facilities offered by the host culture and specifically to the role played by care centers working with refugees. These medico-psychological facilities ${ }^{28}$ can too be seen as constituting a tertiary space, which the subject perceives as "in-between languages" and "in-between worlds." The massive investment of refugee patients in these institutions, "bordering on the medical, outside the traumatic time and space, ${ }^{29}$ where they can meet other exiled persons while receiving care from local staff, also testifies to the necessity felt by those who are without refuge of inscribing themselves in these forms of "tertiary" space.

This phenomenon is widely observed in clinical encounters with refugee subjects, when the transferential relation and the adopted language "allow" certain linguistic flaws to appear, which may then serve the clinician as therapeutic points of attachment. It is fruitful to consider a slip of the tongue or another "linguistic irruption" as a formation of the unconscious - even though some of these patients do not speak French fluently. These unconscious linguistic products are encouraged by the inscription of signs in a new linguistic context, which functions as a trigger of repression and at the same time authorizes its lifting and the return of the repressed content. While the traumatic language seemed smooth and immutable, thanks to the work of psychoanalysis or psychotherapy and by means of the other-language [autre-langue], language itself is able to become a symptom again, which the clinician can interpret and even "do" something with, if he believes that this speech can be interpreted. He must in fact measure his risks, in order not to interpret the uninterpretable - the real - and so avoid making interpretations which would lead to additional narcissistic injuries to the Ego and therefore represent an attack against the protective shield which has already been punctured.

When no such third-person interpreter exists, asking the patient to translate, into his mother tongue, the key signifiers of his history is one way of leading him to place himself in the active position of the translator, helping the displacement of traumatic elements in the here and now, in his own name. The massive dislocation of the psychic subject from the social subject, caused by the traumatic irruption, has often disturbed his relationship to the world. The emergence of a transferential link, based on which the subject can again try to trust another person, encourages the process of translation.

\section{From One Shore to the Other}

"In order to escape, they helped me cross a large river in a canoe, in the middle of the night. I was between life and death." Juliette, a young refugee woman from Congo DRC tells me this story during a therapy session. In her dream, while she is fleeing her war-torn country, she suddenly sees her psychologist appear, helping her and "placing" her in a canoe, so that she can reach the safe city on the other shore - Brazzaville. As the boat is sailing forward and she is heading towards this other shore, far in the distance she sees her doctor, who is watching her and waiting, "ready to receive her," as she puts it. The words Juliette uses to describe her dream echo the definition of the survivor-witness we referred to earlier - the survivor being "stuck" in the gap between life and death.

Juliette has been receiving therapy in a medical center for refugees ${ }^{30}$ for several months. She suffers from severe traumatic disorder, with visual and olfactory hallucinations. The two shores she describes seem to represent her attempts at translating the trauma, the canoe embodying the intermediary link that allows her to leave one place in order to find another. The dream material shows an effort of linking together the memory of her escape, her exile and the unconscious content related to the existing transferential relationship, a transferential intermediary which supports the effort of translation as a meaning-making operation.

This transferential account that Juliette brings into the session shows the young woman's psychical potential in trying to connect the past 
with the present, the here with the over-there, rejection (of her asylum demand) with reception. To resort to the consolidation and/or construction of a reliable bridging, Juliette already has some support: another human being is here to offer her hospitality through language, an other-guarantor who serves as the receiver of her testimony and her person.

In the event of a "territorial and psychical collapse," ${ }^{31}$ the creation of such bridges between the internal and the external world, but also in a more spatial-temporal dimension between the "before there" of the traumatic event and the "after here," is a clinical enterprise which can partially restore symbolization and psychical mobility. In fact, if the subject remains captive to his traumatic present, he will neither be able to project himself into the future, nor imagine an existence that would be different from survival. The "intermediary area" created by the therapist represents an essential clinical tool which gives space to the exiled patient's culture while assigning a central place to his condition of a universal and singular being. These transitive spaces allow the patient's suffering - whether it is connected to his present-day experience, his life before exile or other painful events - to find its place and its elements to progressively intertwine. We therefore distance ourselves from the methods of ethnopsychiatry, which therapeutically focus on the patient's cultural dimension, sometimes to the exclusion of all other aspects. In these approaches, the patient's suffering is treated in relation to his origin and he or she therefore appears forced, in a way, to remain "stuck" to his or her native land.

The clinician contributes to this work of connecting, even to a certain meaning-making process, which aims to allow the subject "attached" to repetition to progressively disentangle himself from various types of action that put him in danger. The often-repetitive nightmares that refugee patients report reveal the strength of the grip of the real, which has taken on a "cinematographic" form. They lead the clinician to work around these moments of imaginary freezing, which have been constructed based on traumatic experience. However, the clinician's task is not to "hunt" for the subject's memories or traumatic dream images. ${ }^{32}$ On the contrary, he can seek to adopt an ethics that encourages the patient to initiate the reappropriation of traumatic scenes that have previously remained in foreign holding. The subjective process of reintegration is begun precisely on the basis of the relationship of transference: the patient partially exteriorizes, onto the therapist, his internal objects, and then internalizes them via structuring projective identification, after adjustment and improvement, but also thanks to the separation that he has been able to operate between the times before and after the event, which the repetition had conflated. ${ }^{33}$

The clinician has neither the power nor the goal of "de-traumatizing" the patient. He nevertheless possesses clinical tools that permit of encouraging the resumption of the processes of binding and thus gradually of blurring the psychical splits. If he considers that the latter can be reduced without putting the patient in danger, he will restore to him the signifiers that are capable of removing him from the traumatic "capture."

Bit by bit, trying to "refasten the drives to the subject of language and language to the body" ${ }^{134}$ allows the subject to extricate himself - at least partially - from the deadly drives which haunt his psychic-somatic apparatus and to recover his capacity of thought and something of a will to live. Transference, which encourages the resumption of psychic circulation, aims to produce representations - an activity necessarily involving the transformation of heterogeneous elements into more homogeneous components. By offering the subject a possibility of "articulating himself," the psychotherapeutic space can give rise to fictionalization and to the production of different traumatic versions, in this way trying to retrace something of his own destiny.

Finally, one of the psychotherapist's tasks consists of gradually dis-identifying the subject from his victim status, which often holds him 
captive, "gives substance to his psychic life" and prevents him precisely from entering a position favorable to the translation of the trauma. Separating oneself from this status is indeed fantasmatically dangerous, tearing the subject away from the semblance of being he sometimes adopts, so that he can give up trying to elaborate what happened to him.

By becoming the author of one's own history, no longer being "passive" with respect to it, the refugee or his heir will be able to redefine the contours of his past and draw the outlines of a new "here".

In this context, we can see that exile indeed works as a metaphor. It facilitates this first translation of one place into another; it authorizes the displacement of elements and hence the production of new symbols, which will carry within themselves an existence other than that of survival.

\section{Bibliography:}

Altounian, J. (1977). Une Arménienne à l'école. Les Temps Modernes. 373/374.

Altounian, J. (1982). Terrorisme d'un génocide. Les temps modernes, 427, 1415-42.

Altounian, J. (2000). La survivance. Traduire le trauma collectif. Paris: Dunod.

Altounian, J. (2003). Ouvrez-moi seulement les chemins d'Arménie. Confluents psychanalytiques. Paris: Les Belles Lettres. Altounian, J. (2005). L'intraduisible: Deuil, mémoire, transmission. Paris: Dunod.

Altounian, V. \& J. (2009). Mémoires du génocide arménien, héritage traumatique et travail analytique. Paris: PUF.

Amhis, Y. (2002). Le corps pour viatique. Actualité du trauma, 119-123, 122. Paris: Érès.

Benjamin, W. (1970). The Task of the Translator (1923). Illuminations. Transl. by Harry Zohn. Glasgow: Fontana/Collins.

Deleuze, G. \& Guattari, F. (1977). Anti-Oedipus. Capitalism and Schizophrenia (1972). New York: Viking Press.

Deleuze, G. (1994). What is Philosophy? London: Verso.

Derrida, J. (1981). Positions. Transl. by Alan Bass. Chicago: University of Chicago Press.

Freud, S. (1920). Beyond the Pleasure Principle. The Standard Edition of the Complete Psychological Works of Sigmund Freud, Volume XVIII (1920-1922): Beyond the Pleasure Principle, Group Psychology and Other Works. Transl. by James Strachey. London: The Hogarth Press and the Institute of Psychoanalysis, 1-64.

Freud, S. (1930). Civilization and its Discontents. The Standard Edition of the Complete Psychological Works of Sigmund Freud, Volume XXI (1927-1931): The Future of an Illusion, Civilization and its Discontents, and Other Works. Transl. by James Strachey. London: The Hogarth Press and the Institute of Psychoanalysis, 57-146.

Guillaumin, J. (1979). Transitivité de la mémoire. Revue française de psychanalyse, 4, 715-723. Paris: PUF.

Imbs, P. (Ed). (1974). Trésor de la Langue française, Dictionnaire de la langue du XIXe et du XXe siècle. Paris: Éditions du CNRS.
Laufer, L. (2005). Quand le traumatisme de la perte a plastiqué la mémoire. La chose traumatique. 97-118, 106. Ed. by F. Chaumon \& V. Meneghini. Paris: L'Harmattan. Sasso, R. \& Villani, A. (2003). Le vocabulaire de Deleuze. Les Cahiers de Noesis, Vocabulaire de la philosophie contemporaine de langue française. Cahier $n^{\circ} 3,86$. Paris: Éditions Vrin, C.N.R.S.

Zaltzman, N. (1998). De la guérison psychanalytique. Paris: PUF.

\section{Notes:}

${ }^{1}$ Derrida, J. (1981). Positions. Transl. by Alan Bass. Chicago: University of Chicago Press, p.26.

2) am namely referring to the Armenian, Jewish, Cambodian and Rwandian genocides, but also to systematic state violence against civil populations, such as for example we saw in the South-American military dictatorships of the 1970s. Although the forms this violence takes vary and should not be confused with one another - a genocide of one nation cannot be equated with the violence against, for example, a member of the army - the resulting threat to life, exile and the feeling of political expulsion generally constitute a common point to all such subjects who have "fallen out of the world." Zaltzman, N. (1998). De la guérison psychanalytique. Series "Epîtres." Paris: PUF, p. 82. The author is citing the words of D.-C. Grabbe's Hanibal, referred to by Freud, S. (1930). Civilization and its Discontents. SE, Volume XXI, p. 64.

Janine Altounian situates "survivance" at the interface between the psychical and the collective. She defines the category as follows: "We may call 'survivance' the unconscious strategy mutually employed by those who have survived a collective catastrophy and their descendants, in order to reconstruct on stilts the precarious foundations of a possible life among those living "normally" in the world in which they have been stranded." Altounian, J. (2000). La survivance, Traduire le trauma collectif. Psychismes. Paris: Dunod, p. 1. 
${ }^{4}$ Altounian, V. \& J. (2009). Mémoires du génocide arménien, héritage traumatique et travail analytique. Paris: PUF.

${ }^{5}$ We are referring to the concept of the "untranslatable", which Altounian introduces and develops in her main work: Altounian, J. (2005). L'intraduisible: Deuil, mémoire, transmission. Paris: Dunod.

${ }^{6}$ As K. Beledian explains, this is the name given to the Armenian genocide (aghed, yeghern). See Beledian, K. "Traduire un témoignage écrit dans la langue des autres". In Altounian, V. \& J. (2009), Op. cit., p. 104.

${ }^{7}$ In addition to having herself undergone analysis, Janine Altounian is part of the editorial team of the new French translation of Freud's complete works at the Presses Universitaires de France, where she is responsible for the consistency of the translations.

${ }^{8}$ Freud, S. (1920). Beyond the Pleasure Principle. SE, Volume XVIII, p.20.

${ }^{9}$ Traducere itself comes from the Latin transduco: to drive across (trans: across / duco: I drive), to cross. In the literal sense, the meaning of the term was originally "to cross a river." It later takes on the figural meaning of "to move from one language to another."

${ }^{10}$ Janine Altounian speaks of "de-portation" from one place to antoher, with all the ambiguity associated with this word (deportation camps), to describe the displacement, the de-portation of "the traumatic collapse of history in the field of representation, in the register of words," L'intraduisible, Op. cit., p. 69.

${ }^{11}$ Benjamin, W. (1970). The Task of the Translator (1923). Illuminations. Transl. by Harry Zohn. Glasgow: Fontana/Collins, p. 73.

${ }^{12}$ Although the " $\mathrm{s}$ " from the prefix "trans-" disappeared from the French term for translation (traduction), it was originally constructed in the same way as the terms "transference" and "transmission."

${ }^{13}$ In particular see Altounian, J. (1977). Une Arménienne à l'école. Les Temps Modernes, 373/374; Altounian, J. (2003). Ouvrez-moi seulement les chemins d'Arménie, Confluents psychanalytiques. Paris: Les Belles Lettres.

${ }^{14}$ Deleuze, G. (1994). What is Philosophy? Transl. by Graham Burchell and Hugh Tomlinson. London: Verso, p. 68.

${ }^{15}$ Sasso, R. \& Villani, A. (2003). Le vocabulaire de Deleuze. Les Cahiers de Noesis, Vocabulaire de la philosophie contemporaine de langue française, Cahier $n^{\circ} 3,86$. Éditions Vrin, C.N.R.S.

${ }^{16}$ Deleuze, G. \& Guattari, F. (1977). Anti-Oedipus. Capitalism and Schizophrenia (1972). New York: Viking Press.
17 "Traumatic experience must be spoken by an other in the language of this other," Altounian writes in L'Intraduisible, Op. cit., p. 128.

${ }^{18}$ Altounian's expression "in several voices" is also taken up by the authors of this collective work.

${ }^{19}$ The books begins with the French translation of Vahram's Diary, followed by the original (in Armenian characters in Turkish). It is followed by Janine Altounian's text "Parcours d'un écrit de survivant jusqu'à son inscription psychique ou Temporalité d'élaboration d'un héritage traumatique" [The trajectory of a survivor's text until its psychic inscription, or The temporality of elaboration of a traumatic heritage]. Op. cit., pp. 113-147. ${ }^{20}$ Chiantaretto, J.-C. (2009). Naissance d'un témoignage, témoignage d'une naissance. Mémoires du génocide arménien, Héritage traumatique et travail analytique (pp. 169-180, p. 170). Op. cit.

${ }^{21}$ Altounian, J. (1982). Terrorisme d'un génocide. Les temps modernes, 427, 1415-42, et Ouvrez-moi seulement les chemins d'Arménie. Un désert aux portes de l'inconscient, Op. cit.

${ }^{22}$ Imbs, P. (Ed.) (1974). Trésor de la Langue française, Dictionnaire de la langue du XIXe et du XXe siècle. Paris: Éditions du CNRS.

${ }^{23}$ Benjamin, W. (1970), Op. cit., p. 71.

${ }^{24}$ Ibid., p. 75.

${ }^{25}$ Ibid., p. 73.

${ }^{26}$ It is interesting to compare French with Spanish. In Spanish, the subject's responsibility is expressed by "hacerse cargo de", which literally means "to take on the burden" of something.

${ }^{27}$ Altounian, J. (2005). Op. cit., p. 122.

${ }^{28}$ In France, a certain number of structures specializing in providing care to refugee populations are open to them and offer medical and psychological services (we are thinking in particular about reception centers such as the Comede (Paris), the association "France Terre d'asile" (Paris), or the Refugees Forum (Lyon), etc.

${ }^{29}$ Altounian, J., Ibid, p. 127.

${ }^{30}$ The facility in question is the COMEDE (Comité Médical d'Aide aux Exilés - Medical Support Committee for Persons in Exile) at the Hospital Kremlin-Bicêtre.

${ }^{31}$ Altounian, J. (2005). Op. cit., p. 143.

${ }^{32}$ Guillaumin, J. (1979). Transitivité de la mémoire. Revue française de psychanalyse, 4, 715-723, 716. Paris: PUF.

${ }^{33}$ Guillaumin, J. Ibid, p. 717.

${ }^{34}$ Amhis, Y. (2002). Le corps pour viatique. Actualité du trauma (pp. 119-123, p. 122). Paris: Érès. 
The authors:

\section{Élise Pestre}

Clinical Psychologist, Practicing Psychoanalyst.

Associate Professor [Maître de Conférences], Psychopathology, Paris Diderot University at Sorbonne Paris Cité; "Politics of health and minorities" Unit (Head), Center for Research in Psychoanalysis, Medicine and Society Lab (EA 3522).

\section{Fethi Benslama}

Clinical Psychologist, Practicing Psychoanalyst.

Professor \& Chair, Psychopathology, Paris

Diderot University at Sorbonne Paris Cité; "Politics of health and minorities" Unit (Head), Center for Research in Psychoanalysis, Medicine and Society Lab (EA 3522).

Campus Paris Rive Gauche

Bâtiment Olympe de Gouges

11, rue Jean Antoine de Baïf

75013 Paris

France

Translated by Kristina Valendinova (revised translation).

\section{Electronic reference:}

Élise Pestre \& Fethi Benslama, "Translation and Trauma", Research of Psychoanalysis [Online], 11|2011 published June 15, 2011.

This article is a translation of Traduction et traumatisme

Full text

\section{Copyright}

All rights reserved 